\title{
LCA AS A TOOL FOR ASSESSING PRODUCT AND PROCESS ORIENTED ECO-INNOVATIONS UNDERTAKEN BY ENTERPRISES
}

\author{
Magdalena Rybaczewska-Błażejowska, Aleksandra Sulerz \\ Kielce University of Technology, Department of Production Engineering, Poland
}

Corresponding author:

Magdalena Rybaczewska-Blażejowska

Kielce University of Technology

Department of Production Engineering

Al. Tysiaclecia Państwa Polskiego 7, 25-314 Kielce, Poland

phone: $(+48) 41$ 342-42-52

e-mail: m.blazejowska@tu.kielce.pl

Received: 17 July 2016

Accepted: 4 January 2017

\begin{abstract}
This paper examines the application of life cycle assessment (LCA) as an approach to foster the product and process oriented eco- innovation of enterprises, using the fruit and vegetable processing plant as an example. LCA, which is traditionally used to assess the impacts of a single product system on the environment, was applied in the enterprise context. This was made possible by forming an indicator describing the environmental profile of an enterprise, which is calculated by the sum of the multiplication of the environmental impact assessment (LCIA) results for individual unit processes within a particular impact category and their weights reflecting the structure of production in an enterprise. In order to distinguish and indicate the direction in which an enterprise should undertake its eco-innovative actions (implementing eco-innovations within the product or production process) the LCIA results are presented individually for products and production processes. The research was conducted in full compliance with the LCA methodology. LCA proved that the analysed enterprise has the largest negative impacts on the environment in the following impact categories: marine eco-toxicity, freshwater eco-toxicity, freshwater eutrophication, human toxicity and natural land transformation. They result primarily from the consumption of thermal and electric energy in the production processes. Therefore, to improve energy efficiency, the enterprise should take eco-innovative actions in the processes applied.
\end{abstract}

KEYWORDS

innovation, eco-innovation, life cycle assessment (LCA), food production.

\section{Introduction}

The concept of innovation, aimed at reducing the environmental impact is variously defined. It is very complex and ambiguous, as it is subject to constant evolution. Thus in practice, several terms referring to the above-mentioned innovations coexist, namely: environmentally friendly, green and eco- [1]. For the purpose of this publication, the authors will use the term eco-innovation, since this term implies a full-life cycle analysis of input and output factors.

According to the OECD definition of innovation, eco-innovation means "the production, assimilation or exploitation of a product, production process, ser- vice or management or business method that is novel to the organisation (developing or adopting it) and which results, throughout its life cycle, in a reduction of environmental risk, pollution and other negative impacts of resources use (including energy use) compared to relevant alternatives" [2].

There are four fundamental types of eco-innovations: product eco-innovation (innovations within products), process eco-innovations (innovations within processes), marketing innovations and organizational innovations.

The first two types of eco-innovations, i.e. ecoinnovations within products and processes (TPP) are referred to as technological eco-innovations [3-5]. 
Many technological eco-innovations may have the characteristics of both product and process innovations.

Product eco-innovations include goods and services that are significantly improved in terms of their negative impact on the environment throughout their life cycle. These may involve: changing the components and materials used, reducing the consumption of natural resources at the manufacturing phase and during the utilisation, extending the time of use and/or reuse and recycling.

Eco-designing is an integral part of product ecoinnovations. It involves an early identification of the environmental aspects associated with the product and their incorporation in the design process [6].

Process eco-innovations mean the implementation of a new or essentially improved method of production or supply in order to diminish the negative impacts on the environment. They usually involve critical changes in the consumption of energy and other natural resources used in the production process or logistics, and therefore are associated with changes in technology, equipment and/or software [6].

This paper aims to present the possibilities of the application of life cycle assessment (LCA) for assessing product and process oriented eco-innovations undertaken by enterprises.

\section{Literature review}

LCA is the most commonly used method of life cycle management (LCM), which enables us to assess the potential impacts of a product system on the environment throughout its life cycle, from the extraction of raw materials, i.e. the cradle, through production, distribution, use, until its final disposal, or the grave $[7,8]$.

An overriding assumption of performing LCA analysis is the increase in efficient use of resources while reducing the environmental burden associated with the product system. The product system means "the collection of unit processes with elementary and product flows, performing one or more defined functions, and which models the life cycle of a product (any goods or service)" [9].

The traditional use of LCA involves: the identification of opportunities to improve the environmental aspects of products at different stages of their life cycle, the comparative assessment of products or their selected unit processes over time, as well as performing relative comparisons between products on the basis of the LCIA results. Currently, LCA is also used to make decisions on strategic planning, pri- oritising environmental management in enterprises, eco-design of goods and making marketing decisions concerning environmental statements, eco-labelling schemes and drawing up environmental declarations $[10,11]$.

The detailed guidelines, principles and requirements on the LCA method are regulated by the ISO 14040:2006 and 14044:2006 standards established by the International Organisation for Standardisation. Their Polish counterparts are PN-EN ISO 14040:2009 - Environmental Management - Life Cycle Assessment - Principles and structure and PNEN ISO 14044:2009 - Environmental Management Life Cycle Assessment - Requirements and guidelines $[9,12]$.

According to the above standards the methodology of LCA includes:

- goal and scope definition,

- life cycle inventory (LCI),

- life cycle impact assessment (LCIA),

- interpretation of the results (see Fig. 1) [13].

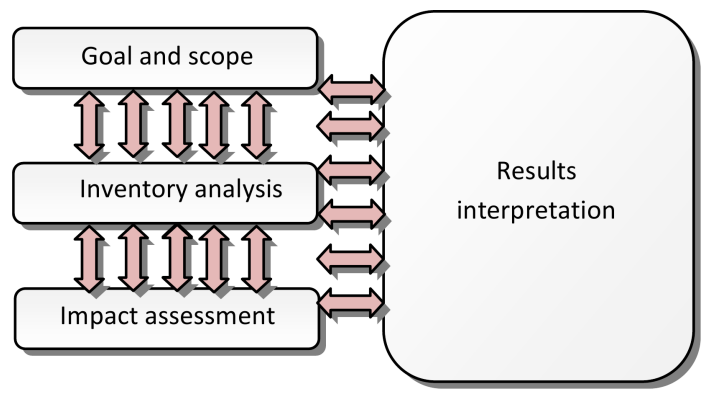

Fig. 1. Model of life cycle assessment (LCA) [13].

At the stage of defining the goal and scope of the LCA analysis, the reason for conducting the research as well as potential recipients of the results and the adopted functional unit are determined. In practice, the goal of the research is determined individually for each LCA analysis. Then the system boundaries are determined. They include unit processes that are the subject of the analysis.

The next stage, which is the inputs and outputs inventory (LCI), involves collecting and quantifying the inputs (product, material and energy flows entering the analysed system) and outputs (product, material and energy flows coming out of the analysed system). It includes the elementary flows (emissions to air, water, soil, non material emissions) and activity flows (electricity, heat, products, auxiliary materials and waste to further treatment) [14].

The third stage, life cycle impact assessment (LCIA), is focused on understanding and evaluating the magnitude and significance of the potential environmental impacts of the examined product system 
[9]. It involves a number of activities, which are divided into mandatory and optional. The mandatory elements of that stage are: the selection of impact categories that represent the environmental problems, category indicators and characterisation models, followed by the assignment of LCI results to the impact categories (classification), and finally the calculation of category indicator results (characterisation). The optional elements of that stage are: the expression of the category indicator results relative to well defined information (normalisation) and the assignment of the category indicator results numerical factors according to their relative importance (weighting). The result of LCIA is the environmental profile of the analysed product [10].

The final stage of the analysis, performed after LCIA, is the interpretation of the results received in the previous stages. It is a phase of the holistic assessment, in which the interrelated results of the life cycle inventory (LCI) are interpreted as well as the results of life cycle impact assessment (LCIA). Next, there are determined the areas in which the implementation of changes will reduce the environmental burden of the analysed product.

\section{Methodology}

LCA is traditionally applied to examine the impacts of individual goods, processes or services on the environment, whereas the authors suggest transferring the so far applied solutions into evaluating product and process oriented eco-innovation of enterprises. It requires rejecting the classical interpretation of the LCA results in favour of creating an environmental profile of an enterprise, taking into account: the structure of production, the source of impacts (product, process) and the reason for their occurrence.

To do so a matrix $\left(M A T_{L C A}\right)$ is formed on the basis of the LCIA results for individual unit processes (products and related to it manufacturing processes) and their weights reflecting the structure of production in a particular enterprise (1). The rows in the matrix represent unit processes, whereas the columns represent environmental impact categories. This notation of the matrix $\left(M A T_{L C A}\right)$ makes it possible to determine the environmental profile of an enterprise. It is a set of sums $S$ of matrix elements $a_{i j}$ for each $j=$ const $(2)$.

$$
M A T_{L C A}=\left[\begin{array}{cccc}
a_{11} & a_{12} & \ldots & a_{1 m} \\
a_{21} & a_{22} & \ldots & a_{2 m} \\
\ldots & \ldots & \ldots & \ldots \\
a_{n 1} & a_{n 2} & \ldots & a_{n m}
\end{array}\right]
$$

$$
S_{j=\mathrm{const}}=\sum_{i=1}^{n} a_{i j}
$$

After designating the environmental profile of the enterprise, the source of impacts (product, process) and the causes of their occurrence are identified. Therefore, it is proposed to analyse the results of the LCA study separately for products and production processes (see Fig. 2). This requires the division and allocation of environmental data between the product and related to it the production process. In case of complex products this might be difficult and thus this needs to be resolved individually from case to case.

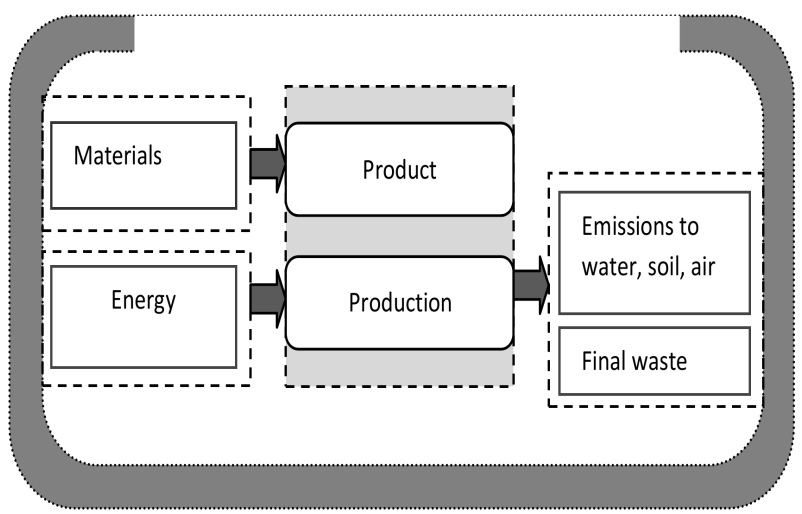

Fig. 2. Separate interpretation of LCA results for product and process.

This assumption seems to be reasonable, since the environmental impacts in enterprises result from, on the one hand, the materials used for manufacturing of goods, and on the other hand, the technology applied in the production processes. This approach makes it possible to distinguish and indicate the direction in which the enterprise should undertake its eco-innovative actions (implementing eco-innovations within the product or production process).

\section{Goal and scope definition}

The study aims to evaluate the eco-innovation through the identification and prioritisation of environmental impacts of a fruit and vegetable processing plant, in terms of manufactured goods and applied production processes. In the long term, the obtained results will make it possible to raise the level of eco-innovation in the analysed enterprises through optimising the use of raw materials, minimizing the amount of waste and improving the energy efficiency of individual production processes identified in the enterprise.

Following the adopted goal of the research, the scope of the analysis includes the products and pro- 
duction processes applied in the fruit and vegetable processing plant. It belongs to a group of large enterprises: has about 600 employees and an extensive machine park. It manufactures a wide range of food products, including frozen fruit and vegetables, fruit preserves (jams, marmalade) as well as fruit and vegetable juices and nectars.

In line with the applied technological instructions of the enterprise, three production lines were listed in the analysed enterprise: the production line of frozen fruit and vegetables, the production line of fruit preserves, and the production line of fruit and vegetable juices and nectars (see Fig. 3).

The production process of frozen fruit and vegetables consists of the four main stages: preprocessing (washing, sorting, purifying, peeling, slicing), final processing (drying with compressed air, blanching, re-sorting), freezing to the temperature below 25 degrees and preparing for transport by placing in the containers with capacity of 150-180 l. Large amounts of water are used at the stage of pre-treatment of fruit and vegetables, which after a single use, in the form of sewage, lands directly in the sanitary sewage system. The next two stages, i.e. final processing and freezing are extremely energy-consuming. Frozen fruit and vegetables are not placed in unit packages.

The production process of fruit preserves consists of three interrelated stages: preparation of fruit and vegetables (sorting, washing and purifying), concen- trating and mixing (cooking of fresh or frozen fruit with sugar, gelling agent and optionally citric acid) and packing in glass unit packaging with capacity of $0.33 \mathrm{l}$. Processing fruit creates wastewater as a result of washing it as well as organic waste (pomace, fruit and vegetable bits, rotten fruit, sorted out fruit, peelings) and packaging waste (foil and waste paper).

The production process of fruit and vegetable juices and nectars consists of four interrelated stages, which include: pre-processing of fruit and vegetables (sorting, washing and purifying), disintegration, pasteurizing and packaging. In the process of disintegration, fruits are exposed to the pressure of rollers of a belt press in order to obtain pulp, from which the semi-dry pomace (organic waste) is transported to the waste box and the juice passes through a sieve belt and then into the buffer tank. In the pasteurization process the juice is heated to a temperature of 78-85 degrees, in order to preserve the manufactured product. At the next stage, the juice is filled into unit packages (glass bottles and PETs with capacity of $0.5 \mathrm{l}, 0.33 \mathrm{l}$ and $0.2 \mathrm{l}$ cartons), which are sterilized with hot air prior to use. The post-process wastewater goes directly to the sanitary sewage system.

In this LCA study, the functional unit of the system is defined as $1 \mathrm{Mg}$ of final product. Consequently, $1 \mathrm{Mg}$ of final product was the point of reference in the inventory of environmental input and output data.

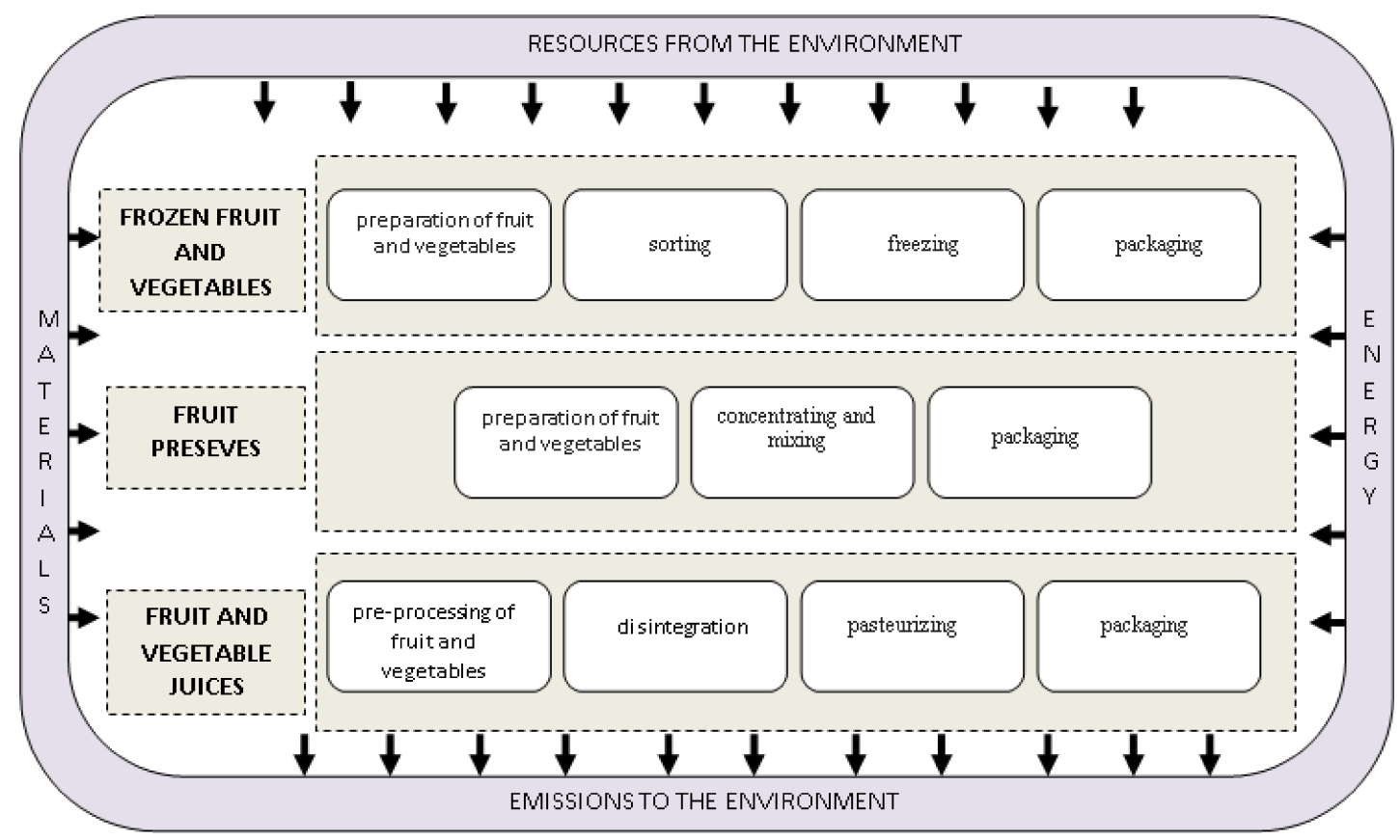

Fig. 3. The scope of LCA analysis and its unit processes. 


\section{Inventory analysis}

In the second stage of the LCA analysis all environmental inputs and outputs were collected and quantitatively determined for individual products and production processes within the system boundaries. As a result a comprehensive catalogue of elementary and activity flows of the analysed enterprise was achieved including, inter alia, used materials (fruit and vegetables), energy (electricity and coal) and water, emissions into air, soil, water (i.e. dust, $\mathrm{SO}_{2}, \mathrm{NO}_{x}, \mathrm{CO}_{2}$ and $\mathrm{CO}$ ) and final waste (fruit and vegetable waste, packaging, slag) (see Figs. 4 and 5). Relevant environmental data was obtained from the examined enterprise by means of a direct interview and a questionnaire.

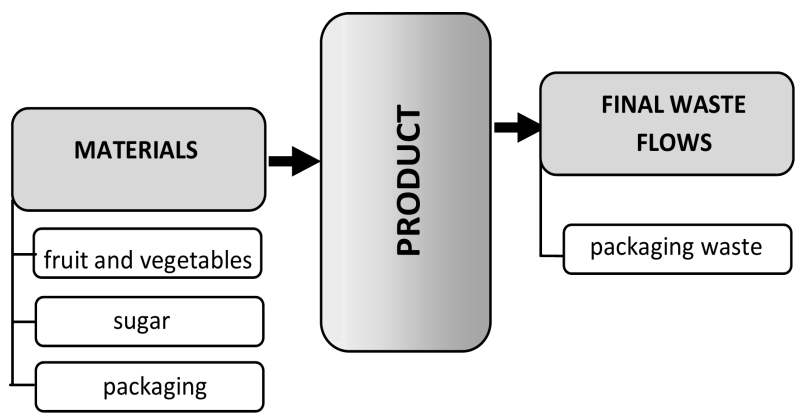

Fig. 4. The general scheme of product inventory analysis.

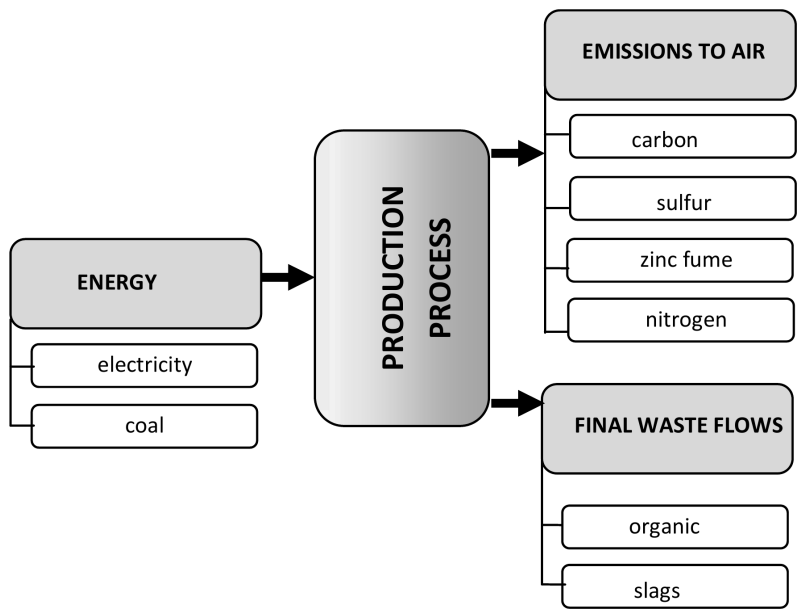

Fig. 5. The general scheme of process inventory analysis.

\section{Results and discussion}

Life cycle impact assessment (LCIA) of the fruit and vegetable processing plant was performed using specialised software SimaPro 8.1 and the ReCiPe Midpoint $(\mathrm{H})$ method. In developing the above method the following assumptions were made: the impacts on the environment are assessed in the long term, environmental data is classified into 18 impact categories and the environmental damages are reversible, if proper technological changes are introduced. The indicator values of impact category were normalised in relation to the average load per one inhabitant in Europe.

Comparative analysis of a normalised environmental profile of $1 \mathrm{Mg}$ of analysed products, i.e. frozen fruit and vegetables, fruit preserves and fruit and vegetable juices and nectars has shown that the greatest negative environmental impacts occur in the following impact categories: natural land transformation (1.32), marine eco-toxicity (1.1), freshwater ecotoxicity (0.95) and human toxicity (0.53) (see Fig. 6). The environmental impacts in the above categories come primarily from fruit preserves.

Comparative analysis of a normalised environmental profile of the production processes of $1 \mathrm{Mg}$ of analysed products, i.e. the production process of frozen fruit and vegetables, the production process of fruit preserves and the production process of fruit and vegetable juices and nectars has shown that the greatest negative environmental impacts occur in the following impact categories: marine eco-toxicity (4.6), freshwater eco-toxicity (3.96), freshwater eutrophication (3.75) and human toxicity (1.7) (see Fig. 7). The environmental impacts in the above categories come primarily from the production process of fruit and vegetable juices and nectars.

Sum of normalised environmental impact profiles of analysed products, i.e. frozen fruit and vegetables, fruit preserves and fruit and vegetable juices and nectars and their production processes proved that the utmost negative environmental impacts occur in the following impact categories: marine ecotoxicity (5.7), freshwater eco-toxicity (4.91), freshwater eutrophication (4.25), human toxicity (2.23) and natural land transformation (1.78) (see Fig. 8). The environmental impacts in the above categories come primarily from fruit and vegetable juices and nectars and their production process.

In order to reflect the production structure of the fruit and vegetable processing plant, individual products and their production processes were assigned weights reflecting the relative proportion of a particular good in the enterprise production. Consequently, frozen fruit and vegetable, fruit preserves and fruit and vegetable juices constitute $73 \%, 7 \%$ and $20 \%$ respectively of the yearly production of the analysed company. 


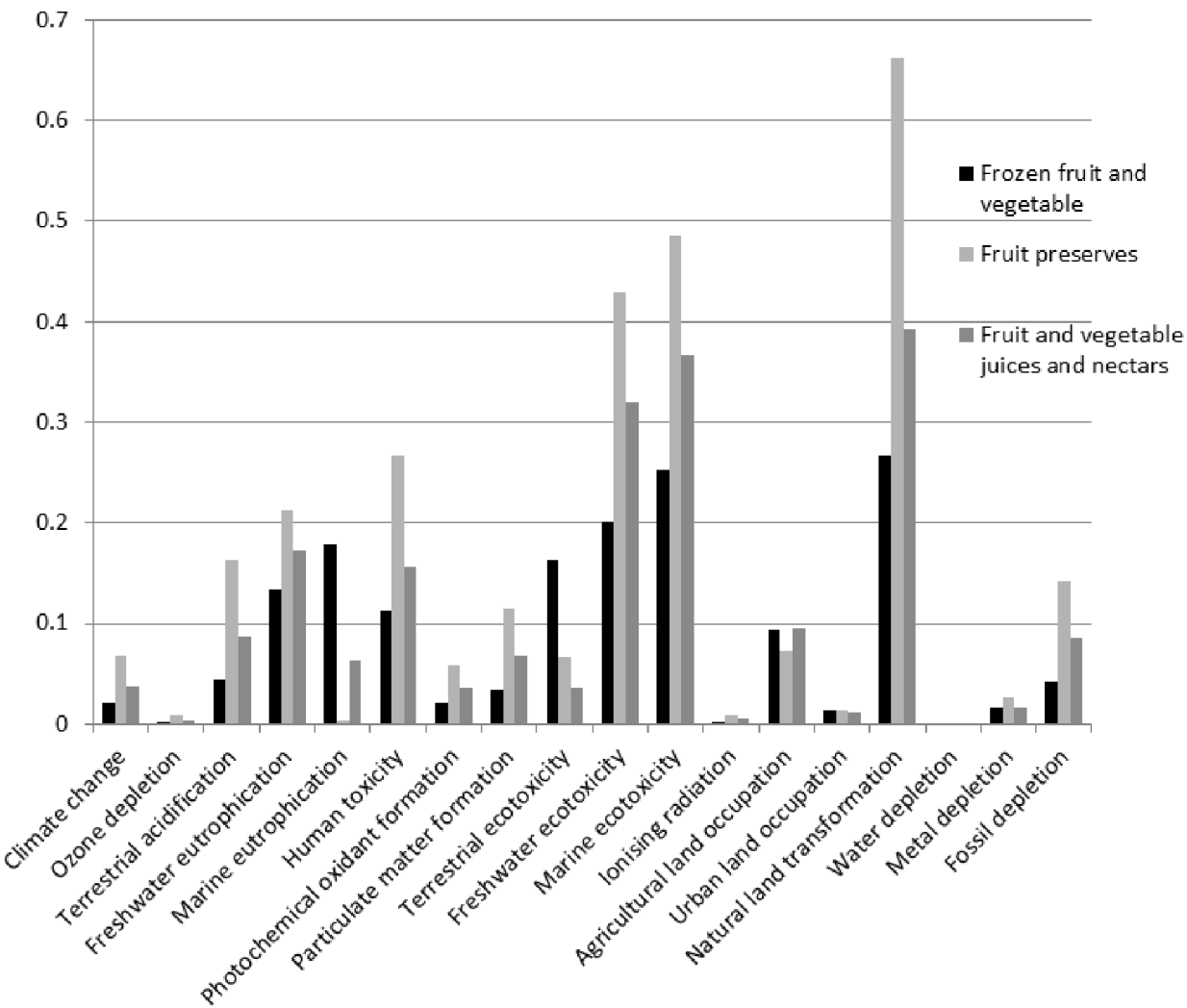

Fig. 6. Normalised environmental profile of $1 \mathrm{Mg}$ of frozen fruit and vegetables, fruit preserves and fruit and vegetable juices and nectars.

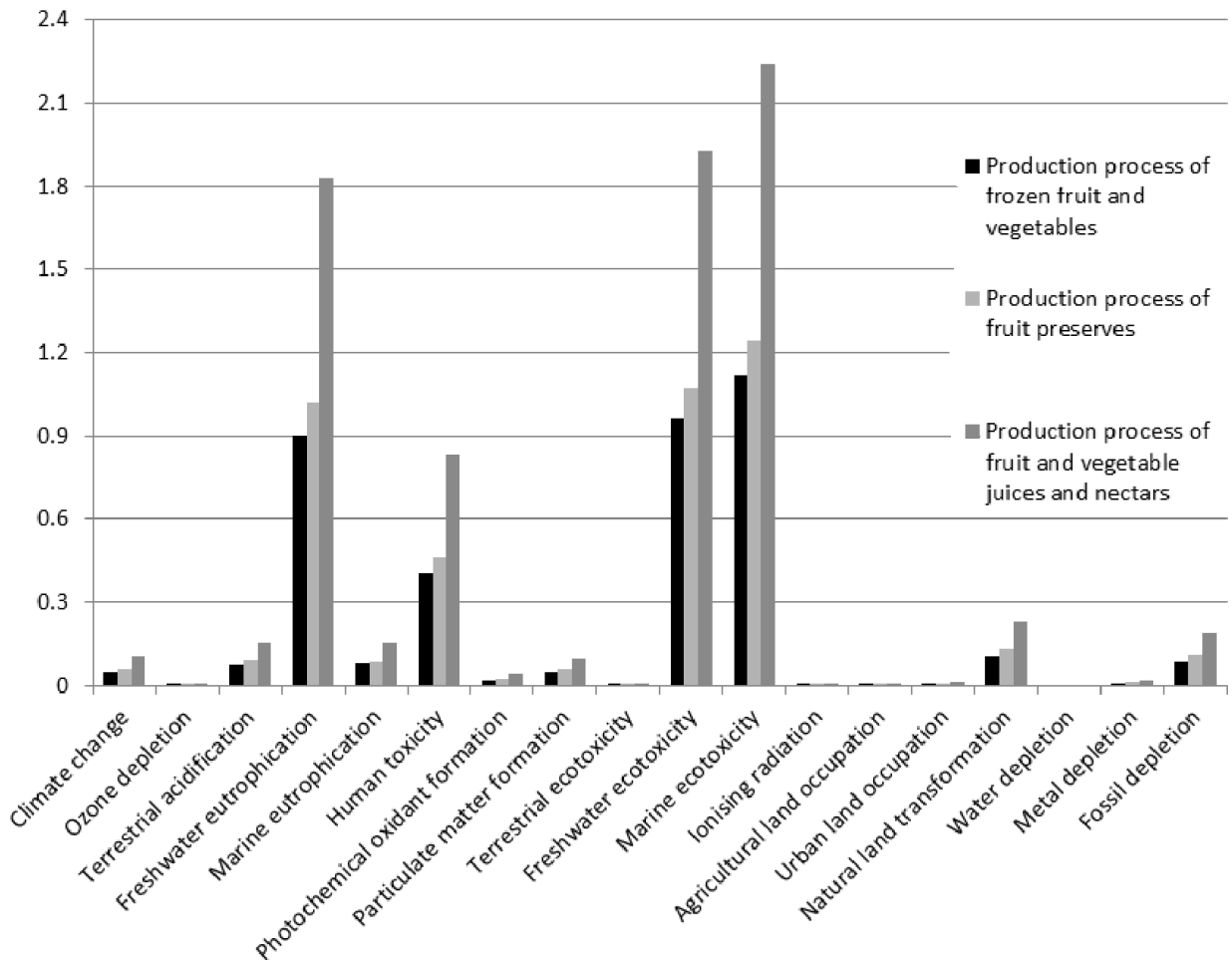

Fig. 7. Normalised environmental profile of the production processes of $1 \mathrm{Mg}$ of frozen fruit and vegetables, fruit preserves and fruit and vegetable juices and nectars. 


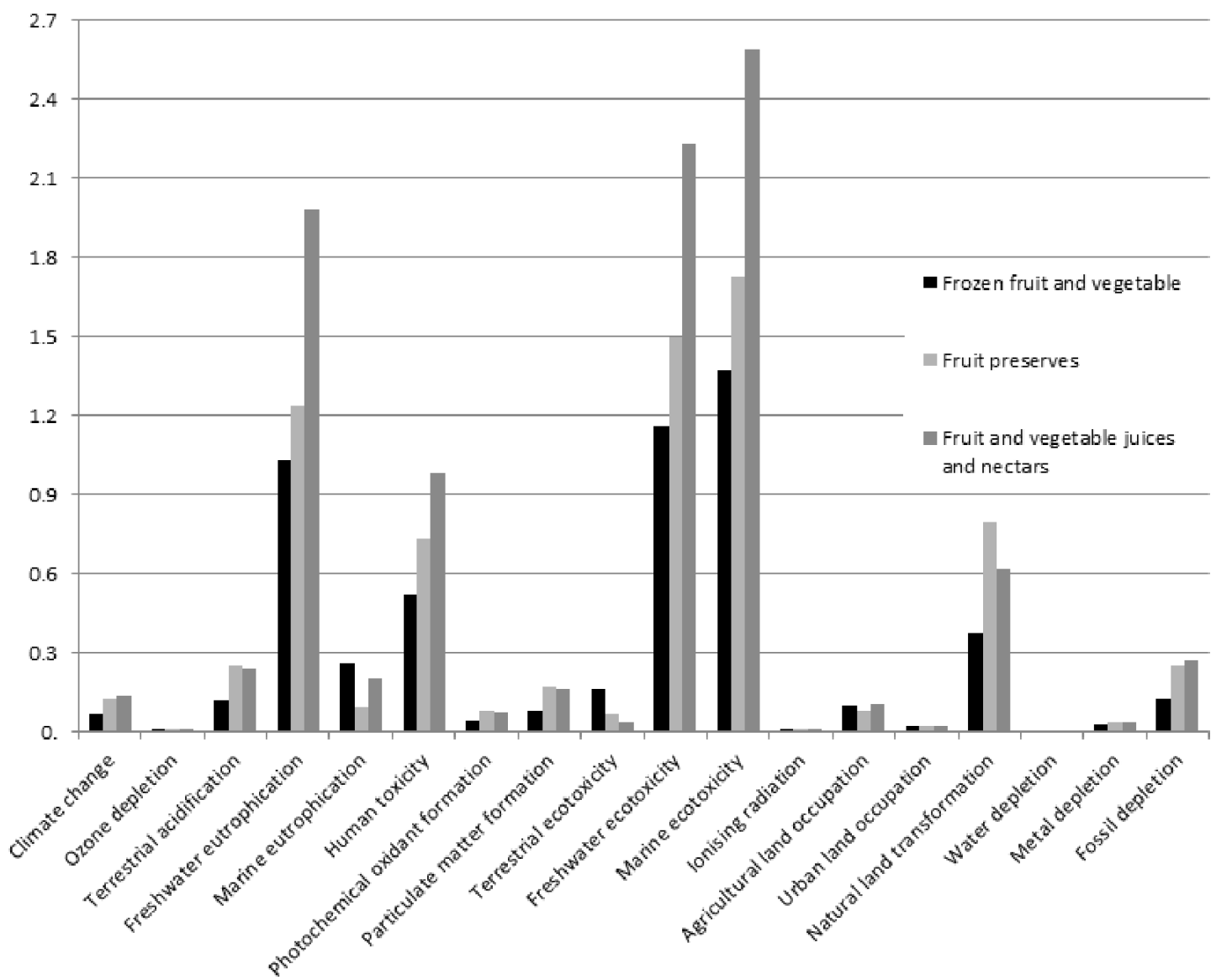

Fig. 8. Normalised environmental profile of $1 \mathrm{Mg}$ of frozen fruit and vegetables, fruit preserves and fruit and vegetable juices and nectars, and their production processes.

The environmental profile of the fruit and vegetable processing plant was presented as a matrix; the rows correspond to individual products and their production processes whereas the columns correspond to particular impact categories (3). In the case of the analysed enterprise rows are respectively: frozen fruit and vegetables, fruit preserves, fruit and vegetable juices and nectars. Due to the fact that the ReCiPe Midpoint $(\mathrm{H})$ method was used in this study the columns represent the following impact categories: climate change, ozone depletion, terrestrial acidification, freshwater eutrophication, human toxicity, photochemical oxidant formation, particulate matter formation, terrestrial ecotoxicity, freshwater ecotoxicity, marine ecotoxicity, ionising radiation, agricultural land occupation, urban land occupation, natural land transformation, water depletion, metal depletion and fossil depletion.

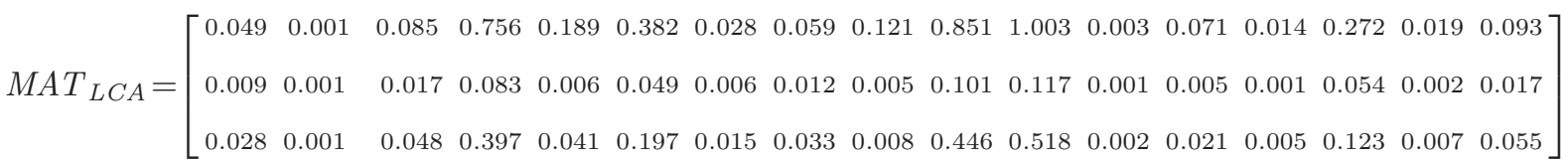


Overall environmental profile of the fruit and vegetable processing plant shows that it generates the largest negative impacts on the environment in the following impact categories: marine ecotoxicity (1.64), freshwater ecotoxicity (1.40), freshwater eutrophication (1.24), human toxicity (0.63) and natural land transformation (0.45) (see Fig. 9).

Taking into consideration the specificity of the examined enterprise, i.e. types of manufactured prod- ucts, applied production processes and the structure of production, the production process of frozen fruit and vegetables is the predominant source of negative impacts on the environment (see Fig. 10). As second, there is the production process of fruit and vegetable juices and nectars. Finally, the remaining production process of fruit preserves and the manufactured food products have the smallest negative impacts on the environment (see Fig. 11).

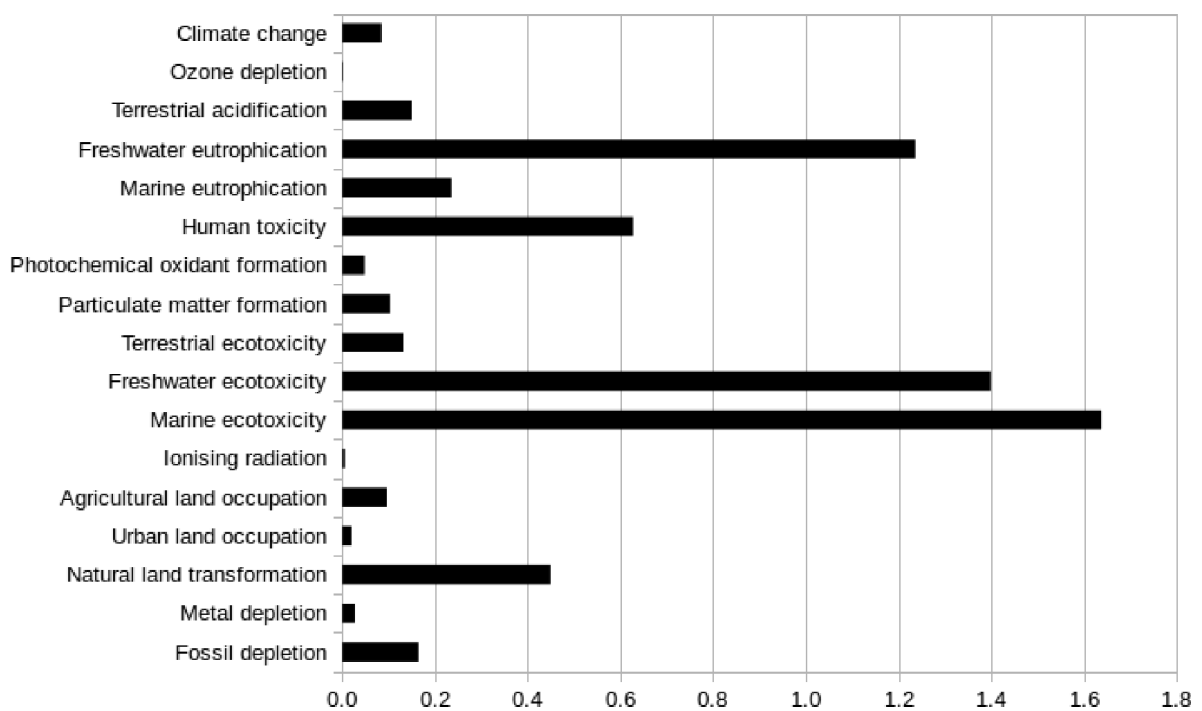

Fig. 9. Overall environmental impact profile of the analysed fruit and vegetable processing plant.

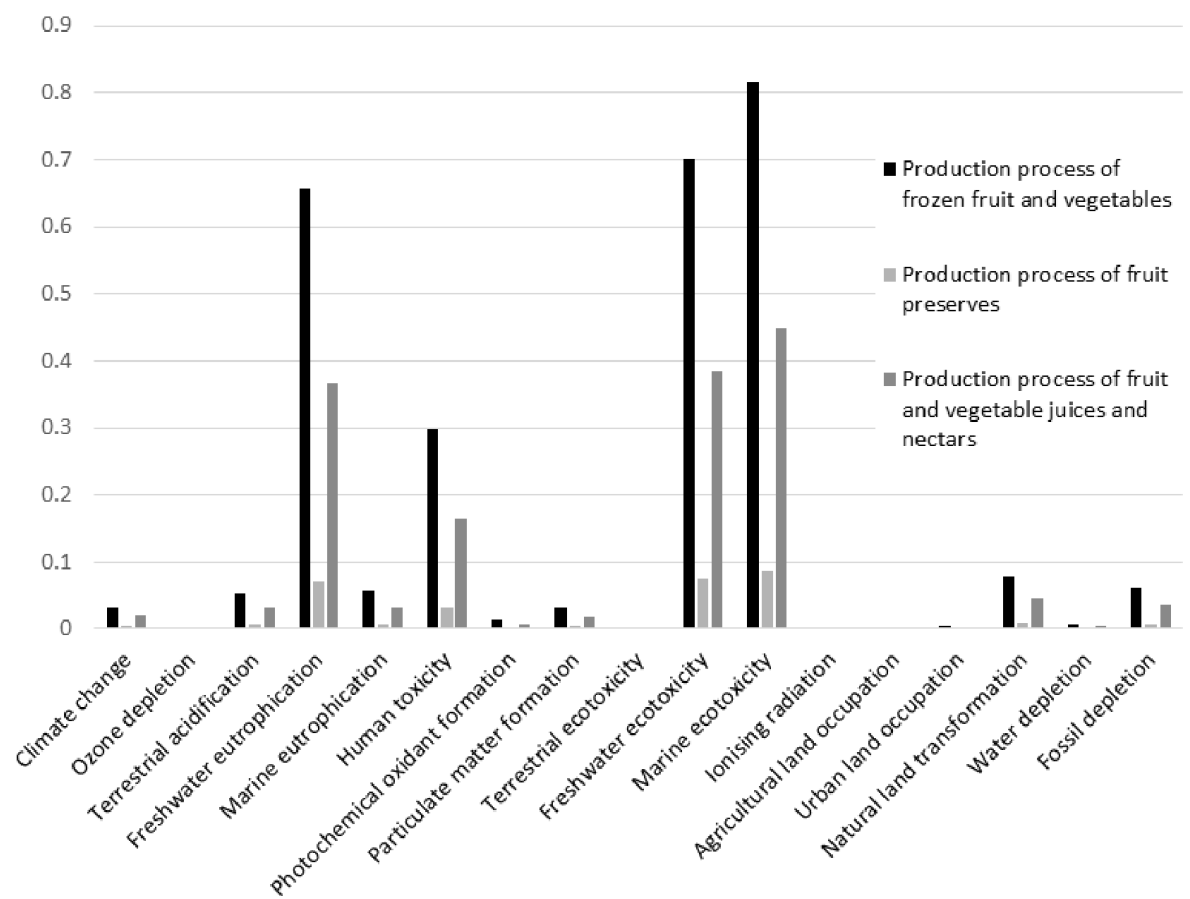

Fig. 10. Weighted normalized environmental impact profile of the production processes of $1 \mathrm{Mg}$ of frozen fruit and vegetables, fruit preserves and fruit juices. 


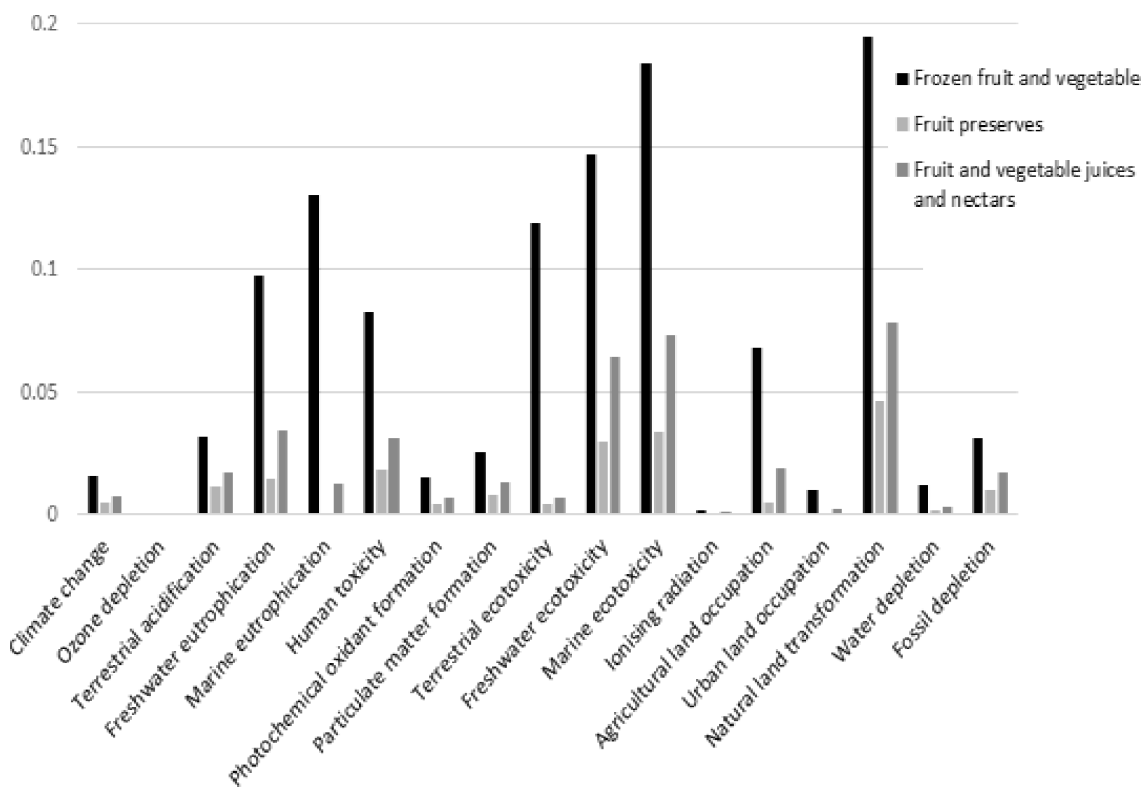

Fig. 11. Weighted normalized environmental impact profile of $1 \mathrm{Mg}$ of frozen fruit and vegetables, fruit preserves and fruit juices.

Using the LCA methodology one can learn not only where the largest impacts on the environment occur, but also the reason for their occurrence. The research has shown that the energy consumption in the production processes is the primary source of environmental impacts in all crucial impact categories. For example, the energy consumption is responsible for $76.2 \%$ of all impacts generated in the category of freshwater eco-toxicity in the production process of frozen fruit and vegetables (see Fig. 12). The results are not surprising, given the fact that technologies applied in the studied enterprise are very high energy consuming. Thus, the greatest demand for thermal energy (steam) is attributed to the following processes: blanching raw materials, cooking fruit preserves and the pasteurization. While the processes of fruit and vegetable sorting, blanching, peeling, pasteurization, freezing and storage are the main receivers of electric energy. The large consumption of energy in the analysed enterprise and using coal for its production is also responsible for significant emissions to the air, in particular $\mathrm{CO}_{2}, \mathrm{CO}, \mathrm{SO}_{2}, \mathrm{NO}_{x}$ and dust.

The production processes are not the only source of environmental contamination, but also materials used for manufacturing of products. The research has shown that there are the impact categories where raw materials and packaging are the dominant source of environmental impacts. For example, in the case of fruit and vegetable juices and nectars, glass packaging and labels account for $48.24 \%$ of all environmental impacts generated in the category of natural land transformation (see Fig. 13).

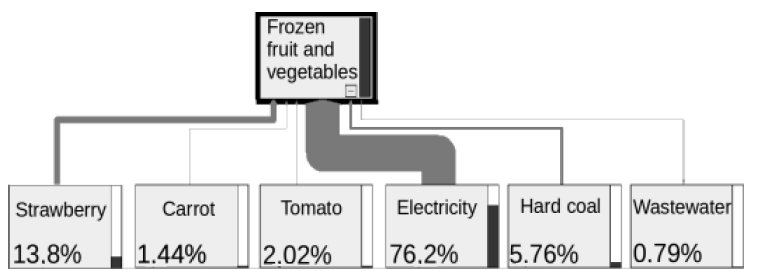

Fig. 12. The process tree of the frozen fruit and vegetables in the category of freshwater eco-toxicity.

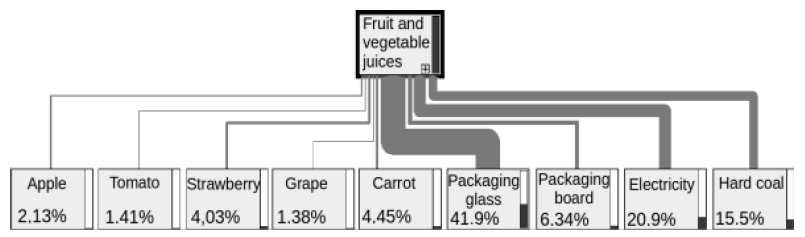

Fig. 13. The process tree of fruit and vegetable juices in the category of natural land transformation.

\section{Conclusions}

The presented research on life cycle assessment of the fruit and vegetable processing plant proved high applicability of the proposed methodology for evaluating and introducing the technological ecoinnovation. In fact, it allows linking the environmental impact assessments of individual products and processes into a single aggregated indicator describing the environmental profile of an enterprise. In addition, it shows directions for implementing the eco-innovative actions, either product or process oriented. 
The study of the technological eco-innovation level of the fruit and vegetable processing plant has shown that it should, in order to minimize its negative impacts on the environment, optimise the production methods, in particular improve the energy efficiency. It can be done, inter alia, by switching off automatically the defrosting evaporators at the time when the cooling tunnels are empty, using proper thermal insulation of pipelines, equipment and buildings, and finally heat recovery from the processes of evaporation, cooking and drying [15]. It ought to be also emphasized that the implementation of the above process oriented eco-innovations will bring the enterprise not only tangible environmental benefits, but also economic ones by reducing production costs.

The methodology proposed by the authors can be applied both at the micro and macro level. On the one hand, though, it might be used by a single enterprise, in order to diagnose its impacts on the environment and indicate the direction of implementing the technological eco-innovative actions. On the other hand, it might be used to make an analysis of enterprises from the same sector from the given region, in order to make a comparative analysis of their impacts on the environment within a given impact category. Consequently, the proposed methodology and our results should be an impulse for further and more detailed analysis of the technological ecoinnovation of enterprises, including other products and production processes.

\section{$\underline{\text { References }}$}

[1] Díaz-García C., González-Moreno Á., Sáez-Martínez F., Eco-innovation: insights from a literature review, Innovation, 17, 1, 6-23, 2015.

[2] Kemp R., Pearson P., Final report of the MEI project measuring eco-innovation, http://www.oecd. org/env/consumption-innovation/43960830.pdf, p. 7, 2007.

[3] The Oslo Manual, Guidelines for Collecting and Interpreting Innovation Data. The Measurement of scientific and technological activities, Joint publication of OECD and Eurostat Polish edition MNiSW, pp. 47-65, Warsaw 2006.

[4] Baran J., Ryszko A., Development and implementation of technological eco-innovations and eco-designintegration of processes and methodological guidelines for their implementation [in Polish: Opracowywanie $i$ wdrażanie ekoinnowacji technicznych a ekoprojektowanie - integracja procesów i wskazówki metodyczne ich realizacji], Innovations in Management and Production Engineering [Innowacje w zarządzaniu i inżynierii produkcji], Oficyna Wydawnicza Polskiego Towarzystwa Zarządzania Produkcją, pp. 34-46, 2013.
[5] Szpor A., Śniegocki A., Eco-innovation in Poland: The present state, development barriers, support opportunities [in Polish: Ekoinnowacje w Polsce: Stan obecny, bariery rozwoju, możliwości wsparcia], Instytut Badań Strukturalnychpp. 3-8, Warszawa 2012 .

[6] PKN-ISO/TR 14062:2004, Environmental management-incorporation of environmental aspects in designing and developing manufacturing products [in Polish: Zarzadzanie środowiskowe - Wtaczenie aspektów środowiskowych do projektowania i rozwoju wyrobów].

[7] Masternak-Janus A., Rybaczewska-Błażejowska M., Life cycle analysis of tissue paper manufacturing from virgin pulp or recycled waste paper, Management and Production Engineering Review, 6, 3, 4754, 2015.

[8] Kowalski Z., Kulczycka J., Góralczyk M., Life cycle assessment of manufacturing processes [in Polish: Ekologiczna ocena cyklu życia procesów wytwórczych $(L C A)$ ], Wydawnictwo Naukowe PWN, p. 102, 2007.

[9] PE-EN ISO 14040:2009, Environmental management - life cycle assessment - principles and structure [in Polish: Zarzadzanie środowiskowe - Ocena cyklu życia - Zasady i struktura].

[10] Masternak-Janus A., Rybaczewska-Błażejowska M., Life Cycle Assessment (LCA) - methodology and applicability [in Polish: Ocena cyklu życia (LCA) metodologia i możliwości zastosowania], Contemporary conditions of development of socio-economic World-Poland-Świętokrzyskie region, Kielce University of Technology, pp. 506-517, 2014.

[11] Grzesik K., Introduction to life cycle assessmentnew techniques in environmental protection [in Polish: Wprowadzenie do oceny cyklu życia (LCA)nowej techniki $w$ ochronie środowiska], Inżynieria Środowiska, 11, 1, 101-113, 2006.

[12] PN-EN ISO 14044:2009, Environmental management - life cycle assessment - requirements and guidelines [in Polish: Zarzadzanie środowiskowe Ocena cyklu życia - Wymagania $i$ wytyczne].

[13] Tukker A., Handbook on Life Cycle Assessment, New York Boston Dordrecht London Moscow, Kluwer Academic Publishers, p. 19, 2002.

[14] Barański A., Gworek B., Bojanowicz-Bablok A., Life cycle assessment. Theory and practice [in Polish: Ocena cyklu życia. Teoria i praktyka], Warszawa: Institute of Environmental Protection - National Research Institute, pp. 24-39, 2011.

[15] https://www.mos.gov.pl/fileadmin/introduction/ images/Wytyczne_dla_branzy_spozywczej_-_przetworstwo_owocowo-warzywne. pdf (Guidelines for food industry-fruit and vegetable processing). 